\title{
Decreased antibiotic susceptibility and enhanced probiotic production potential of goat milk fermented curd in comparison with cow and buffalo milk
}

\author{
JYOTI LAKHANPAL, JEENA GUPTA* \\ Department of Bioengineering and Biosciences, Lovely Professional University (LPU), Phagwara, Punjab, India
}

\begin{abstract}
The present study was carried out to characterize and compare the production potential and antibiotic susceptibility of probiotics isolated from goat, cow and buffalo milk. The probiotics isolated from milk fermented curd were compared with regard to their number, morphology, gram staining, motility, bile salt tolerance, pH-resistance, catalase activity, oxidase production and antibiotic resistance. We demonstrated that the probiotics isolated from milk fermented curd of all three species were gram positive, motile, catalase negative, and oxidase negative and were able to produce lactic acid. Further, we observed that buffalo milk is more potent in forming curd with the highest count of probiotics per $\mathrm{ml}\left(3.53 \times 10^{-5}\right)$ as compared to cow $\left(5.8 \times 10^{-6}\right)$ and goat milk $\left(7 \times 10^{-7}\right)$; moreover, goat milk bacterial isolates were more tolerant to acidic $\mathrm{pH}$ but were less bile-salt tolerant than cow milk. Also, probiotics isolated from goat milk curd were more resistant to antibiotics (resistant to 12 out of 15 screened antibiotics) than those from cow and buffalo milk (resistant to 8-9 antibiotics). This report shows that goat milk fermented products possess the highest antibacterial potential and are highly acid-tolerant.
\end{abstract}

Key words: probiotics, goat milk, antibiotic resistance, buffalo milk, cow milk, curd

\section{Introduction}

The term "probiotic" (used by Lilly and Stillwell for the first time in 1965) refers to non-pathogenic microorganisms (bacteria and yeast), which when ingested reach the intestines in sufficient numbers to confer health benefits to a host (Schrezenmeir and De Vrese, 2001). The most commonly used bacterial probiotics include Lactobacillus, Bifidobacterium, Streptococcus, and some Enterococcus species (Morrow et al., 2012). Intake of probiotics stimulates the growth of beneficial microorganisms and reduces the number of pathogens, thereby improving the microbial balance of the host and reducing the risk of gastrointestinal diseases (Fuller and Cross, 1991; Cross, 2002). Probiotics have been reported to have anticarcinogenic, anti-mutagenic, anti-hypertensive, antiosteoporosis, and immunomodulatory effects (Chiang, 2012). A recent report has demonstrated that probiotics can also enhance the effect of allergen specific immunotherapy (AIT) on allergic asthma (Liu et al., 2016).

As it is highly nutritious, milk is also a rich source of probiotics (Aydenova et al., 2013). Probiotics are responsible for the anti-oxidant properties of fermented milk which can be further enhanced by additives such as cocoa, coffee, tea and fruit pulps (Najgebauer-Lejko and Sady, 2015). Probiotics such as Lactobacillus bulgaricus, and Streptococcus thermophiles are used in the manufacture of yogurts from milk. Other species such as Lactobacillus lactis, Lactobacillus acidophilus, and Lactobacillus casei are used for the production of cultured milk, ripened cheese, and butter (Zhang et al., 2015). The unique presence of probiotic microorganisms in the intestinal epithelium and gastrointestinal tract, and their traditional use in fermented foods prove their safety (Pangallo et al., 2008). 
Probiotics are also known to possess intrinsic antibiotic resistance that is considered a desirable trait to recover intestinal microflora after the extensive use of antibiotics (Broaders et al., 2013). Lactic acid bacteria are known to possess resistance against a variety of antibiotics, e.g. beta-lactams, macrolides, aminoglycosides, chloramphenicol and tetracycline classes (Sharma et al., 2014; Davirgiliis et al., 2013). However, certain studies have reported that probiotics, especially Lactobacillus species, also act as a reservoir of antibiotic resistance genes and are responsible for their transfer to pathogenic organisms in the intestinal lumen (Mater et al., 2008). The screening of probiotics for antibiotic resistance could therefore serve as a platform for in depth characterization of determinants of antibiotic resistance.

As per nutrition parameters, cow milk contains less fat than buffalo milk, but a higher level of cholesterol which may be linked to various health problems, i.e. intolerance ranging from atopic dermatitis, constipation and diarrhea. About $25 \%$ infants around the world suffer from a cow milk allergy due to the high content of casein (milk protein) (Ruszczyński et al., 2016). Goat milk has been described as having higher digestibility, which leads to a smaller number of allergic reactions than is the case with cow milk (Alferez et al., 2001). It has also been reported to have a balance of essential amino acids, high levels of calcium, selenium, phosphate, and to be rich in vitamins $\mathrm{A}$ and $\mathrm{B}$, but deficient in folic acid and vitamin D (Alferez et al., 2006; Riberio et al., 2010). Furthermore, goat milk contains bioactive components such as angiotensin converting enzymes (ACE), inhibitory peptides, and peptide hypertensive agents which are responsible for providing immunity to non-immune diseases and controlling microorganism infections (Hayes et al., 2006).

Nahar and coworkers compared cow, goat and buffalo milk for their physical and chemical compositions, i.e. proteins, fats, and total solid and ash content (Nahar et al., 2007). However to the best of our knowledge, this is the first report that directly compares cow, goat and buffalo milk in terms of their probiotic potential and antibiotic resistance. The aim of our study was to isolate probiotics from the milk of different animals (cow, buffalo and goat) and characterize and compare these to obtain a clear picture of their nutritional benefits and their role in human health and physiology. Our results show that buffalo and goat milk are better than cow milk, as they exhibit greater probiotic potential, $\mathrm{pH}$ tolerance and better antibiotic resistance.

\section{Materials and methods}

In this study, all the cultivation mediums and chemicals were provided by Hi-Media Co (India), including MRS (Man-Ragosa-Sharpe) agar, MRS broth, catalase, oxidative disks, and Gram straining kits. The Bile salt agar medium was provided by $\mathrm{CDH}$ Co (India).

\section{Collection of samples}

A total of 3 milk samples of cow, buffalo and goat were randomly collected from different producers at the same time in sterilized bottles from different areas of Ludhiana, India. All milk samples were boiled to kill microbes and the standard curd inoculum was introduced in all as starting cultures. The preparation was then allowed to ferment into curd for 7-8 $\mathrm{h}$ at room temperature $\left(30-35^{\circ} \mathrm{C}\right)$. The prepared samples were then kept in a refrigerator to stop the fermentation process and to preserve samples for future use.

\section{Isolation of probiotics}

To isolate the probiotics from milk samples we followed a standard microbiological procedure (Kale, 2014). Briefly, the curd samples were serially diluted from 10 to $10^{-9}$ under aseptic conditions. From these dilutions, the $10^{-5}, 10^{-7}, 10^{-9}$ and $10^{-12}$ diluted samples were spread-plated (in triplicate) on MRS agar medium and the plates were then kept in an incubator at $37^{\circ} \mathrm{C}$ for $24 \mathrm{~h}$. After the incubation, well-isolated colonies were counted using a colony counter and were identified using standard morphological, culture and biochemical reactions. The selected colonies were then separated by streaking on fresh MRS agar plates.

\section{Total viable count}

The colonies observed were counted using a colonycounter. The Colony Forming Units (CFU) were calculated and the total viable count per microlitre was determined using the formula as follows:

The viable count per microlitre of the curd samples is:

$$
\begin{aligned}
\text { Bacteria } / \text { microlitre } & =\mathrm{CFU} \div \text { dilution factor } \\
& \times \text { amount of sample }
\end{aligned}
$$

CFU - colony forming units (number of colonies); dilution factor - colonies observed at a particular dilution; 
amount of sample - amount of curd sample spread on the MRS agar.

\section{Gram staining of colonies}

Gram staining was performed according to the standard method by Collins and coworkers (Collins et al., 2004). The morphology of isolated colonies was examined under a light electronic microscope at a magnification of $10 \times, 40 \times$ and $100 \times$.

\section{Catalase test}

The production of catalase is indicated by the breakdown of $3 \%$ hydrogen peroxide to release oxygen as effervescence and water molecules.

\section{Oxidase activity test}

The oxidative disk test was used to determine if microorganisms possessed the cytochrome oxidase enzyme. The appearance of a deep purple/deep blue color indicated positive results, while no change in color indicated negative results.

\section{Motility test}

For the identification of motile bacteria, the hangingdrop wet method was used (MacFaddin et al., 2000). For this investigation, the depression slide with hanging drop was observed under an electronic microscope at a magnification of $40 \times$ and $100 \times$, respectively.

\section{Lactose utilization test}

The lactose utilization test was performed to determine the production of lactic acid by bacteria (Thoesen et al., 1994). A change in the color of the broth (to yellow) indicated that the bacteria had produced lactic acid, while no change in color showed no lactic acid production.

\section{Characterization of probiotic properties}

\section{Bile salt resistance}

The characterization of isolated bacteria was conducted on the basis of their resistance to bile salt (Niazi Amraii et al., 2014). The sub-cultured bacterial colonies were inoculated $(10 \% \mathrm{w} / \mathrm{v})$ into MRS broth and incubated at $37^{\circ} \mathrm{C}$ for $24 \mathrm{~h}$. Loopfuls of overnight-grown fresh cultures were streaked on MRS agar (containing 0.3\% $(\mathrm{w} / \mathrm{v})$ bile salt) and kept at $37^{\circ} \mathrm{C}$ for $24 \mathrm{~h}$. Only bile resistant bacteria grew on agar.

\section{pH testing}

Acid tolerance of isolated bacterial species was determined by their growth in broths with different $\mathrm{pH}$ (Niazi Amraii et al., 2014). The MRS broth was prepared in $100 \mathrm{ml}$ sterilized flasks, $\mathrm{pH}$ was adjusted to 2, 2.5, 3, 3.5, 4, 5 and 6 using $\mathrm{HCl}$ or $\mathrm{NaOH}$. Nutrient broths with $\mathrm{pH} 3,4$ and 5 were used as controls. Inoculums of isolated bacteria grown overnight were introduced into test tubes containing $5 \mathrm{ml}$ of each media with varying $\mathrm{pH}$ and kept at $37^{\circ} \mathrm{C}$ for $24 \mathrm{~h}$. Growth was observed after $24 \mathrm{~h}$ in the form of turbidity.

\section{Antibiotics resistance test}

The antibiotic susceptibility test was used to determine which antibiotic affected probiotic growth in the tested curds (Huys et al., 2002). Using the Disk Diffusion Method, the antibiotic resistances of probiotic strains were assessed with a Hi-Media Antibiotic Disk. Fresh cultures of isolated bacteria grown overnight from buffalo, cow, and goat were spread on Muller-Hinton Agar (MHA) using cotton swabs. The antibiotic disks used were ampicillin/sulbactum $(10 / 10 \mu \mathrm{g})$, amoxycillin $(30 \mu \mathrm{g})$, ampicillin $(25 \mu \mathrm{g})$, clindamycin $(10 \mu \mathrm{g})$, cefotaxime $(10 \mu \mathrm{g})$, chloramphenicol $(25 \mu \mathrm{g})$, cefoxitin $(30 \mu \mathrm{g})$, kanamycin $(5 \mu \mathrm{g})$, methicillin $(30 \mu \mathrm{g})$, meropenem $(10 \mu \mathrm{g})$, neomycin $(30 \mu \mathrm{g})$, oxacillin $(1 \mu \mathrm{g})$, penicllin-G (10 units), streptomycin $(25 \mu \mathrm{g})$, and tetracycline $(10 \mu \mathrm{g})$. These antibiotics disks were placed on the MHA surface. The plates were incubated at $37^{\circ} \mathrm{C}$ for $24-36 \mathrm{~h}$ and the results were recorded afterwards.

\section{Statistical analysis}

Experimental values are expressed as means \pm SEM. A comparison of mean values between various groups was performed by one way-analysis of variance (one wayANOVA). $P$-value $<0.05$ was considered to be significant.

\section{Results}

\section{Physical characteristics of cow, goat and buffalo milk fermented curd}

Curd was prepared by adding identical and equal amounts of curd inoculum as initial cultures to pasteurized milk samples obtained from cow, goat and buffalo. The physical (organoleptic) characteristics of the three curd samples were ascertained (Table 1). We observed 
Table 1. Comparison of organoleptic characteristics of curd prepared from cow, buffalo and goat

\begin{tabular}{c|c|c|c|c}
\hline $\begin{array}{c}\text { Number } \\
\text { of } \\
\text { species }\end{array}$ & Parameters & Goat & Cow & Buffalo \\
\hline 1 & color & creamy-white & yellowish-golden & creamy-white \\
\hline 2 & texture & thin (liquid form) & thick & very thick \\
\hline 3 & taste & sweet & slightly acidic & acidic \\
\hline 4 & smell & odorless & slightly acidic & highly acidic \\
\hline 5 & time of curdling & $24-25$ hours & $12-14$ hours & $7-8$ hours \\
\hline
\end{tabular}

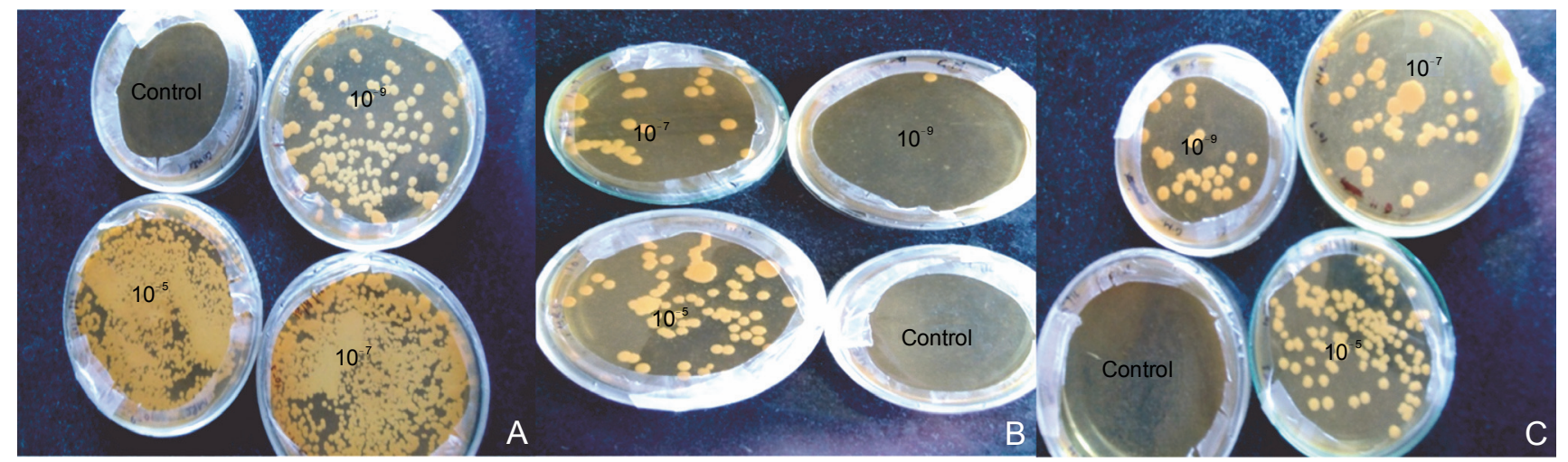

Fig. 1. Probiotic colonies from the tested curd. The curd samples were serially diluted from 10 to $10^{-9}$ under aseptic conditions. From these dilutions, $10^{-5}, 10^{-7}, 10^{-9}$ and $10^{-12}$ were selected. The spread plate technique was used to introduce bacteria onto MRS agar medium, and the plates were then kept in an incubator at $37^{\circ} \mathrm{C}$ for 24 hours. Images shown above are (A), cow (B) and goat $(\mathrm{C})$. Experiments were performed in triplicate

that curd from cow milk was yellowish-golden in color, whereas goat and buffalo milk curd were creamy white. The time taken for curding of goat milk was almost twice as long (24-25 $\mathrm{h})$ as that for cow milk (12-14 h) and even longer than that of buffalo milk (curdles in 7-8 h). Even then, the goat milk curd was more liquid in form, whereas the buffalo milk curd appeared to be the thickest. This was consistent with a previous report which had showed that due to the higher fat content in the buffalo milk, the thickness and consistency of the curd was the highest (Nahar et al., 2007). The goat milk, on the other hand, contained much less fat, and thus showed a softer consistency. In addition, we also observed that the goat milk was odorless and sweeter than the cow and buffalo milk curd; the latter was also more acidic in taste.

\section{Comparison of the total viable count of probiotic species in cow, goat and buffalo milk fermented curd}

Since the same curd inoculum was used, the colonies were observed for growth and morphological fea- tures. The colonies were small-sized, white to cream in color and round without any pigmentation (Fig. 1). Colony Forming Units (CFU) from all the above mentioned dilutions for each curd sample were estimated using a Bacterial Colony Counter. The results are collated in Table 2. Buffalo fermented milk showed the highest number of CFUs $(121 \pm 7.767)$ and goat fermented milk showed the lowest $(2 \pm 1.53)$ at $10^{-9}$ dilution. Further, we also evaluated the Total Viable Bacterial Count (Table 2), which is the number of viable bacteria present per microlitre of sample in each of the fermented milk samples, and we observed the highest count in buffalo milk $\left(3.53 \times 10^{-5}\right)$, followed by cow $\left(5.8 \times 10^{-6)}\right.$ and goat milk $\left(7 \times 10^{-7}\right)$ at $10^{-9}$ dilution.

\section{Characterization of the probiotic species isolated from} cow, goat and buffalo milk fermented curd

The characterization of isolated probiotic species from the colonies obtained from milk fermented curd of cow, goat and buffalo milk was conducted using the 
Table 2. Number of colonies formed and the total viable count of probiotics from cow, goat and buffalo at different dilutions (experiments were performed in triplicate $(n=3)$ )

\begin{tabular}{c|c|c|c|c|c}
\hline Number & $\begin{array}{c}\text { Milk } \\
\text { sample }\end{array}$ & $\begin{array}{c}\text { Dilution rate }\left(10^{-5}\right) \\
\text { number of colonies }\end{array}$ & $\begin{array}{c}\text { Dilution rate }\left(10^{-7}\right) \\
\text { number of colonies }\end{array}$ & $\begin{array}{c}\text { Dilution rate }\left(10^{-9}\right) \\
\text { number of colonies }\end{array}$ & $\begin{array}{c}\text { Total viable } \\
\text { count }\end{array}$ \\
\hline 1 & goat & $44 \pm 9.643^{*}$ & $22 \pm 2.081^{*}$ & $2 \pm 1.527$ & $7 \times 10^{-7}$ \\
\hline 2 & cow & $52 \pm 5.507^{* *}$ & $36 \pm 7.211^{*}$ & $19 \pm 4.509^{*}$ & $5.8 \times 10^{-6}$ \\
\hline 3 & buffalo & $190 \pm 7.767^{* * *}$ & $169 \pm 5.508^{* * *}$ & $121 \pm 14.29^{* * *}$ & $3.53 \times 10^{-5}$ \\
\hline
\end{tabular}

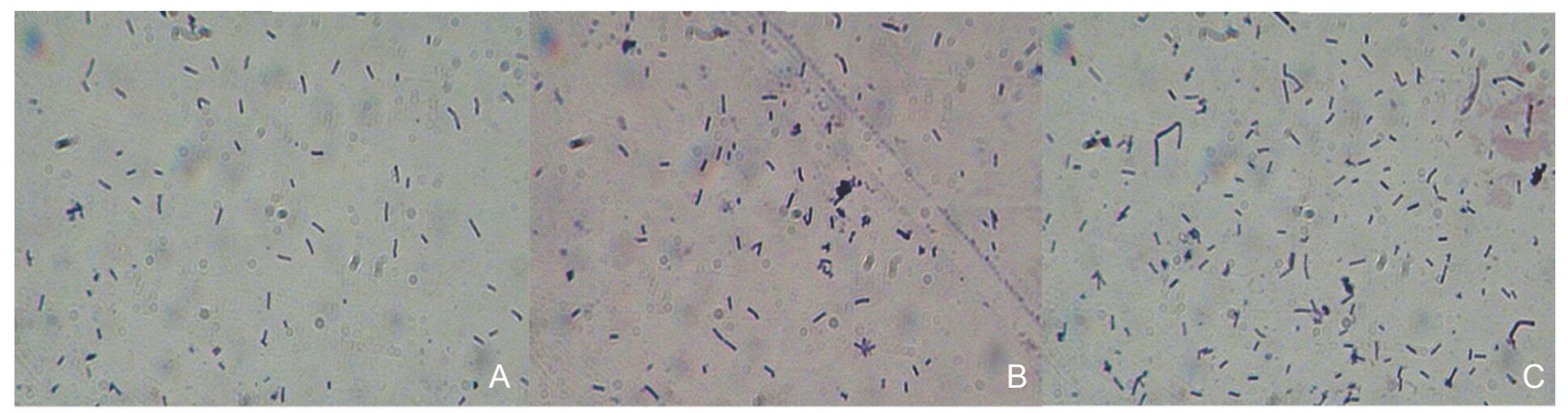

Fig. 2. Digital microscopic image for Gram staining of isolated bacteria of goat, cow and buffalo curd at 100×. Gram staining was conducted according to the method by Collins and coworkers (Collins et al., 2004). The morphological and culture examination of the isolated colonies was performed and colonies were observed under a light electronic microscope at 100× magnification

following: Gram staining procedure, catalase test, oxidase test, mobility test and lactose fermentation test.

\section{Gram staining}

Following the standard gram staining method, we observed that the colonies selected from all the three samples appeared to be purple in color, i.e. they were gram-positive. They were all rod-shaped, and appeared in either singles or in doubles (Fig. 2).

\section{Catalase test}

Effervescence or bubble production after addition of $\mathrm{H}_{2} \mathrm{O}_{2}$ indicates a positive catalase test. No effervescence was seen in any of the test tubes after the addition of $\mathrm{H}_{2} \mathrm{O}_{2}$. This indicated that the isolated probiotic bacterial stains could not mediate the decomposition of $\mathrm{H}_{2} \mathrm{O}_{2}$ to produce oxygen and were therefore catalase negative.

\section{Oxidase test}

For the oxidase test, the overnight grown bacterial cultures were poured onto the oxidative disks. There was no change in the color and appearance of oxidase disks due to the isolated bacteria from all three samples.
This showed that all the isolated probiotic bacterial stains were oxidase negative.

\section{Motility test}

Using the hanging-drop wet method, we observed that all the isolated probiotic bacterial cultures from all the samples were non-motile. This is a characteristic feature of Lactobacilli spp. Thus, the isolated bacteria from all curd samples resembled the characteristics of the Lactobacillus spp.

\section{Lactose utilization test}

In the lactose-utilization test, the production of lactic acid by the bacteria was confirmed. This test resulted in a change of the color of the broth, which indicated that the isolated probiotic bacterium was capable of producing lactic acid. Due to this characteristic, Lactobacilli $\mathrm{sp}$. is also known as Lactic Acid Bacteria (LAB).

From all the performed biochemical tests (Table 3), we concluded that the bacteria isolated from the curd samples of cow, goat and buffalo may belong to the Lactobacillus species, as they possess the characteristics typical for Lactobacillus. Further confirmatory tests 
Table 3. The results of biochemical tests to identify pure cultures of cow, goat and buffalo milk samples (all experiments were performed in triplicate)

\begin{tabular}{c|c|c|c|c|c|c}
\hline Number & $\begin{array}{c}\text { Milk } \\
\text { sample }\end{array}$ & $\begin{array}{c}\text { Gram } \\
\text { staining }( \pm)\end{array}$ & $\begin{array}{c}\text { Catalase } \\
\text { test }( \pm)\end{array}$ & $\begin{array}{c}\text { Lactose } \\
\text { fermentation test }( \pm)\end{array}$ & $\begin{array}{c}\text { Oxidase } \\
\text { test }( \pm)\end{array}$ & $\begin{array}{c}\text { Motility } \\
\text { test }( \pm)\end{array}$ \\
\hline 1 & goat & + & - & + & - & non-motile \\
\hline 2 & cow & + & - & + & - & non-motile \\
\hline 3 & buffalo & + & - & + & - & non-motile \\
\hline
\end{tabular}

were performed on the curd samples, in order to check the probiotic potential of the isolated strains.

\section{Bile salt tolerance and $\mathrm{pH}$ tolerance of isolated probiotic bacterial species from cow, goat and buffalo milk}

\section{Bile salt resistance test}

One important property of probiotics is that they are able to resist the inhibitory factors present in the gastrointestinal tract, such as bile salt. For this purpose, the effect of $0.3 \%$ of bile salt (high concentration) on the growth of isolated probiotic bacteria on the MRS agar was investigated. The result (Table 4) showed that all the isolated bacteria had the ability to resist the bile salts at $0.3 \%$ concentration. However, some variations were observed in the curd samples. The bacteria isolated from buffalo curd samples were more bile-salt resistant than those from cow or goat curd samples.

Table 4. Comparison of bile salt resistance of bacteria from different milk sources

\begin{tabular}{c|c|c}
\hline Number & Samples & Results \\
\hline 1 & goat & + \\
\hline 2 & cow & ++ \\
\hline 3 & buffalo & +++
\end{tabular}

Tests were performed in triplicate $(n=3):(+)$ small tolerance, $(++)$ moderate tolerance, $(+++)$ high tolerance

\section{pH testing}

Another characteristic property of probiotics is their ability to grow at different $\mathrm{pH}$, generally in the acidic range. The major selection criterion for probiotic strains is their ability to resist low $\mathrm{pH}$ (Cakir, 2003). The results of the bacteria cultures grown in media with different $\mathrm{pH}$ conditions were observed and recorded (Table 5). The appearance of turbidity of the media in the $\mathrm{pH}$ range from 3.5 to 7 indicated that the isolated probiotic strains from all the three species had the ability to grow in neutral and acidic conditions.
Table 5. Effect of different $\mathrm{pH}$ on the growth of probiotics isolated from different milk sources

\begin{tabular}{c|c|c|c}
\hline $\begin{array}{c}\text { Sample } \\
\text { pH }\end{array}$ & Goat & Cow & Buffalo \\
\hline 2.0 & - & - & - \\
\hline 2.5 & - & - & - \\
\hline 3.0 & - & - & - \\
\hline 3.5 & + & - & + \\
\hline 4.0 & + & ++ & +++ \\
\hline 5.0 & +++ & +++ & +++ \\
\hline 6.0 & +++ & +++ & +++ \\
\hline 7.0 & ++ & - & + \\
\hline
\end{tabular}

All experiments were performed in triplicate: $(-)$ no growth, $(+)$ slight growth, $(++)$ good growth, $(+++)$ very good growth $(n=3)$

Antibiotic susceptibility of isolated probiotic bacterial species from cow, goat and buffalo milk

Using the Disk Diffusion method, different antibiotic disks were introduced onto the Muller-Hinton Agar (MHA) containing bacterial cultures. After 24 hours, the growth of bacteria with respect to the antibiotics was observed. The zones of inhibition indicated the extent of the bacteria's inability to survive in the presence of antibiotics, whereas clear zones or smaller zones of inhibition indicated the resistance of the bacterial isolates to the respective antibiotics (Table 6 ). We observed that probiotics isolated from goat milk curd were more resistant to antibiotics (resistance toward 12 antibiotics and sensitivity toward 3 ) as compared to cow (resistant to 9 , sensitive to 4 and with intermediate results to 2 antibiotics) and buffalo (resistant to 8 , sensitive to 5 and with intermediate results to 2 antibiotics). This clearly showed that goat milk was more beneficial in aiding the recovery of intestinal microflora after the use of the tested antibiotics. 
Table 6. Effects of different antibiotics on the growth of isolated probiotic strains from different species curds

\begin{tabular}{|c|c|c|c|c|c|c|}
\hline $\begin{array}{l}\text { Number } \\
\text { of species }\end{array}$ & $\begin{array}{l}\text { Zone of inhibition } \\
\text { by antibiotic disk }\end{array}$ & Abbreviations & $\begin{array}{l}\text { Disk units } \\
\text { [ug] }\end{array}$ & Buffalo & Cow & Goat \\
\hline 1 & Ampicillin/Sulbactum & $\mathrm{A} / \mathrm{S}^{10 / 10}$ & 43017 & $\begin{array}{c}21 \pm 2.08^{* *} \\
\mathrm{~S}\end{array}$ & $\begin{array}{c}19 \pm 1.527^{* *} \\
\mathrm{~S}\end{array}$ & $\begin{array}{c}17 \pm 2.516^{*} \\
\mathrm{~S}\end{array}$ \\
\hline 2 & Amoxycillin & $\mathrm{AMX}^{30}$ & 30 & $\begin{array}{l}14 \pm 2.08^{*} \\
\mathrm{I}\end{array}$ & $\begin{array}{c}16 \pm 2.645^{*} \\
\mathrm{I}\end{array}$ & $\begin{array}{c}12 \pm 2 \\
\mathrm{R}\end{array}$ \\
\hline 3 & Ampicillin & $\mathrm{AMP}^{10}$ & 25 & $\overline{\mathrm{R}}$ & $\overline{\mathrm{R}}$ & $\begin{array}{c}7 \pm 1.732^{*} \\
\mathrm{R}\end{array}$ \\
\hline 4 & Chloramphenicol & $\mathrm{C}^{30}$ & 25 & $\begin{array}{c}23 \pm 4.163^{*} \\
\mathrm{~S}\end{array}$ & $\begin{array}{c}21 \pm 2.081^{* *} \\
\mathrm{~S}\end{array}$ & $\begin{array}{c}18 \pm 2.08^{*} \\
\mathrm{~S}\end{array}$ \\
\hline 5 & Clindamycin & $\mathrm{CD}^{2}$ & 10 & $\begin{array}{c}17 \pm 1^{* *} \\
\text { I }\end{array}$ & $\begin{array}{c}9 \pm 2.039^{*} \\
\mathrm{R}\end{array}$ & $\begin{array}{c}8 \pm 2.081 \\
\mathrm{R}\end{array}$ \\
\hline 6 & Cefotaxime & $\mathrm{CTX}^{30}$ & 10 & $\begin{array}{c}20 \pm 1^{* *} \\
\mathrm{R}\end{array}$ & $\begin{array}{c}16 \pm 2^{*} \\
\mathrm{R}\end{array}$ & $\begin{array}{c}15 \pm 3.055^{*} \\
\mathrm{R}\end{array}$ \\
\hline 7 & Cefoxitin & $\mathrm{CX}^{30}$ & 30 & $\begin{array}{c}18 \pm 1^{* *} \\
\mathrm{~S}\end{array}$ & $\begin{array}{c}13 \pm 2.5166^{*} \\
\mathrm{I}\end{array}$ & $\begin{array}{c}13 \pm 1.527^{*} \\
\mathrm{R}\end{array}$ \\
\hline 8 & Kanamycin & $\mathrm{K}^{30}$ & 5 & $\begin{array}{c}16 \pm 1.527^{*} \\
\mathrm{R}\end{array}$ & $\overline{\mathrm{R}}$ & $\overline{\mathrm{R}}$ \\
\hline 9 & Methicillin & $\mathrm{MET}^{5}$ & 30 & $\overline{\mathrm{R}}$ & $\overline{\mathrm{R}}$ & $\overline{\mathrm{R}}$ \\
\hline 10 & Meropenem & $\mathrm{MRP}^{10}$ & 10 & $\begin{array}{c}14 \pm 0^{* * *} \\
\mathrm{R}\end{array}$ & $\begin{array}{c}13 \pm 1.527^{*} \\
\mathrm{R}\end{array}$ & $\begin{array}{c}15 \pm 2.081^{*} \\
\mathrm{R}\end{array}$ \\
\hline 11 & Neomycin & $\mathrm{N}^{30}$ & 30 & $\begin{array}{c}11 \pm 1.527^{*} \\
\mathrm{R}\end{array}$ & $\begin{array}{c}13 \pm 2.516^{*} \\
\mathrm{R}\end{array}$ & $\begin{array}{c}6 \pm 2.516 \\
\mathrm{R}\end{array}$ \\
\hline 12 & Oxacillin & $\mathrm{OX}^{1}$ & 1 & $\overline{\mathrm{R}}$ & $\overline{\mathrm{R}}$ & $\overline{\mathrm{R}}$ \\
\hline 13 & Penicllin-G & $\mathrm{P}^{2}$ & 10-units & $\begin{array}{l}- \\
\mathrm{R}\end{array}$ & $\begin{array}{l}- \\
\mathrm{R}\end{array}$ & $\begin{array}{l}- \\
\mathrm{R}\end{array}$ \\
\hline 14 & Streptomycine & $\mathrm{S}^{10}$ & 25 & $\begin{array}{c}18 \pm 1^{* *} \\
\mathrm{~S}\end{array}$ & $\begin{array}{c}15 \pm 2.51^{*} \\
\mathrm{~S}\end{array}$ & $\begin{array}{c}12 \pm 2.516 \\
\mathrm{R}\end{array}$ \\
\hline 15 & Tetracycline & $\mathrm{TE}^{30}$ & & $\begin{array}{c}25 \pm 1^{* * *} \\
\mathrm{~S}\end{array}$ & $\begin{array}{c}21 \pm 1.52^{*} \\
\mathrm{~S}\end{array}$ & $\begin{array}{c}16 \pm 2^{*} \\
\mathrm{~S}\end{array}$ \\
\hline
\end{tabular}

$\mathrm{R}$ - resistance, I - intermediate or S - sensitive) concluded on the basis of Zone Size Interpretative Chart using MHA ( $n=3)$; all experiments were performed in triplicate; all values are represented as means \pm S.E.M. ${ }^{* * *} P<0.001,{ }^{* *} P<0.01$ and ${ }^{*} P<0.05$

\section{Discussion}

Milk and fermented milk products (curd) are beneficial for human health, as they provide supplements which help to maintain the intestinal balance associated mainly with the presence of different probiotic bacteria (Mokoena et al., 2016). Curd is the most preferred dairy product due to its high probiotic potential. In this study, three different types of curd (cow, goat and buffalo) were prepared and analyzed on the basis of their physical qualities and probiotic potential. The color and texture of the curd prepared from goat and buffalo milk were similar; however, in the cow curd a golden-yellowish color appeared, indicating a higher carotene content (Nahar et al., 2007). The curd from goat milk was sweeter in taste than cow or buffalo milk curd.

The isolation of probiotic bacteria was conducted using a serial-dilution method from curd of all three species. A comparison was performed on the basis of colony forming potential. The results showed that the buffalo curd produced the highest number of colonies, resulting in the highest Colony Forming Unit (CFU) value (Fig. 1 and Table 1); whereas the goat sample gave the lowest number of colonies, which resulted in the lowest CFU value. We concluded, therefore, that curd obtained from 
buffalo milk offered the highest probiotic potential as compared to cow and goat curd and was consequently much more beneficial for human health.

The colonies isolated from all three test samples were creamy to white in color. On the basis of a microscopic examination, morphological and cultural characteristics were determined. Gram-staining of the bacterial culture showed that all the isolated strains from all three species were Gram positive, rod shaped and non-motile (Fig. 2, Table 3). The catalase test showed inability to produce bubbling when mixed with $3 \% \mathrm{H}_{2} \mathrm{O}_{2}$, which indicated the absence of a catalase enzyme, a characteristic feature of Lactobacillus sp. Further, no change in the color of oxidase disks confirmed that the isolated bacteria did not contain cytochrome oxidase enzyme, another property of Lactobacillispecies. We also performed the Lactose Utilization Test to confirm that the isolated bacteria could produce lactic acid. A phenol red lactose broth medium was used as an indicator. All the curd samples resulted in a change of color from red to yellow, which indicated that the isolated bacteria were capable of producing lactic acid. As the isolated probiotics showed characteristic features of Lactobacillus, they were determined as being Lactic Acid Bacteria (LAB).

The bacteria to be used as probiotics should have the potential to resist the inhibitory factors present in the gastrointestinal tract, e.g. the bile salts and low $\mathrm{pH}$, as they have to pass through the stressful conditions of the stomach (Cakir, 2003). The isolated probiotic strains were screened for their ability to tolerate bile salts and low $\mathrm{pH}$ conditions. The results indicated that bacteria isolated from buffalo curd showed the highest bile salt tolerance as compared to cow or goat curd (Table 4). Further, bacteria isolated from goat and buffalo curd showed turbidity from $\mathrm{pH}=3.5$ to $\mathrm{pH}=7$ MRS broth, highlighting their ability to grow in low $\mathrm{pH}$ (Table 5). The main difference occurred at $\mathrm{pH}=7$, where goat bacterial isolates showed good growth, while those from the buffalo curd showed only a slight growth. The cow bacterial isolates started showing turbidity at $\mathrm{pH}=4$. We, therefore, concluded that bacterial isolates of goat curd were viable in a wider $\mathrm{pH}$ range (3.5-7), while those from buffalo curd could not survive at $\mathrm{pH}=7$. Also, bacteria isolated from cow curd showed normal growth from $\mathrm{pH}=4$ to $\mathrm{pH}=6$. Standard probiotic strains were stable from $\mathrm{pH}=3$ to 7 , but sensitive to $\mathrm{pH}=9$, as had been shown by Alpay and coworkers (Alpay et al., 2003).
We further screened the nature of resistance of probiotics isolated from curd samples to fifteen different types of antibiotics (Table 6). The results were interpreted based on the Hi-Media Zone Size Interpretative Chart. Antibiotics such as ampicillin, sulbactum, chloramphenicol, and tetracycline affected the growth of bacteria, producing large zones of inhibition, which proved that they were sensitive (Table 6). The majority of the isolated probiotic strains were highly resistant (no or little effect) to eight different antibiotics, although not all to the same extent. The bacterial strains isolated from goat curd proved to be highly resistant, showing resistance against 12 out of 15 antibiotics, while the buffalo bacterial isolates showed lower resistance (resistant to 8 out of 15), and were mainly affected by cefoxitin and clindamycin. Thus, goat curd showed the strongest probiotic potential in comparison with cow or buffalo curd. Based on previous reports, we can state that these probiotics represent a reservoir of antibiotic resistance genes and the ingestion of these probiotics may influence the presence, establishment, and dynamics of antibiotic resistance bacteria after antibiotic ingestion during disease treatments (Gueimonde et al., 2013). These probiotic strains comply with the FAO/WHO (2002) criteria and may be used to prevent enteric bacterial infection (FAO/WHO, 2002).

Dairy products are important for human health. This comparative study of cow, goat and buffalo fermented milk products has revealed that probiotics isolated from goat, cow and buffalo curd are $\mathrm{pH}$-tolerant from acidic to neutral growth conditions, bile- salt tolerant at $0.3 \%$ concentration and resistant to most of the antibiotics tested. Our results clearly show that goat milk fermented products possess the highest antibacterial potential. Recently, a study by Chen and coworkers has also demonstrated the optimization of the formulation of a probiotic goat milk tablet which can be used to provide health benefits by maximizing the probiotic viable count (Chen et al., 2014).

\section{Conclusions}

From this comparative study, we concluded that the goat milk fermented product showed the highest antibacterial potential and was highly acid-tolerant. Prominent probiotics present in goat curd help in the maintenance of the normal microbial flora of the intestines, as they can resist the acidic conditions of the stomach and small intestines and show resistance to many antibiotics. 
These probiotics also have the potential to prevent side effects arising from antibiotic therapy and may help to strengthen the immune system.

The authors declare that no conflict of interest exists with the publication of this study.

\section{References}

Alferez M.J.M., Lopez A.I., Nestares T., Campos M.S. (2006) Dietary goat milk improves iron bioavailability in rats induced ferropenicanaemia in comparison to cow milk. Intern. Dairy J. 16: 813-821.

Alférez M.J., Barrionuevo M., López Aliaga I., Sanz-Sampelayo M.R., Lisbona F., Robles J.C., Campos M.S. (2001) Digestive utilization of goat and cow milk fat in malabsorption syndrome. J. Dairy Res. 68: 451-461.

Alpay S., Aydin F., Kilich S.S. (2003) Antimicrobial activity and characteristics of bacteriocins produced by Lactobacilli. Turk. J. Med. Sci. 33: 7-13.

Aydenova N.N., Iliev T., Mihaylova G. (2013) Fatty acids and lipid indices of buffalo milk yogurt. Agricult. Sci. Technol. 5: 331-334.

Broaders E., Gahan C.G., Marchesi J.R. (2013) Mobile genetic elements of the human gastrointestinal tract: potential for spread of antibiotic resistance genes. Gut. Microbes. 4(4): 271-280.

Cakir I. (2003) Determination of some probiotic properties on Lactobacilli and Bifidobacterium. Ankara University Thesis of Ph.D.

Chen H., Zhang J., Shu G. (2014) Screening of probiotic goat milk tablets using Plackett-Burman design. Acta Sci. Pol. Technol. Aliment. 13: 351-358.

Chiang P. (2012) Beneficial effects of Lactobacillusparacasei subspecies NTU 101 and its fermented products. Appl. Microbiol. Biotechnol. 93: 903-916.

Collins C.H., Lyne P.M., Grange J.M. (2004) Collins and Lyne's microbiological methods. 8th edition. ButterworthHeinemann, London.

Cross M.L. (2002) Microbes versus microbes: immune signals generated by probiotic lactobacilli and their role in protection against microbial pathogens. FEMS Immunol. Med. Microbiol. 34: 245-253.

Dave R.I., Shah N.P. (1996) Evaluation of media for selective enumeration of Streptococcus thermophilus, Lactobacillus delbrueckii ssp. bulgaricus, Lactobacillus acidophilus, and bifidobacteria. J. Dairy Sci. 79: 1529-1536.

FAO/WHO (2002) Food and agricultural organization of the United Nations and World Health Organizations: Guidelines for the evaluation of probiotics.

Fuller R., Cross M. (1991) Probiotics in human medicine. Gut 32: 439-442.

Gueimonde M., Sánchez B.G., de Los Reyes-Gavilán C., Margolles A. (2013) Antibiotic resistance in probiotic bacteria. Front Microbiol. 18: 202.

Halder D., Mandal S. (2015) Curd Lactobacilli with probiotic potentiality. Translat. Biomed. 6: 1.
Hayes M., Ross R.P., Hill C. (2006) Casein derived antimicrobial peptides generated by Lactobacillus acidophilus. Appl. Environ. Microbiol. 72: 2260-2264.

Huys G., D’Haene K., Swings J. (2002) Influence of the culture medium on antibiotic susceptibility testing of foodassociated lactic acid bacteria with the agar overlay disc diffusion method. Lett. Appl. Microbiol. 34(6): 402-406.

Kale P.S. (2014) Isolation and identification of bacteria from curd and its application in probiotic chocolate. Eur. J. Exp. Biol. 4(6): 95-97.

Liu J., Chen F.H., Qiu S.Q., Yang L.T., Zhang H.P., Liu J.Q., Geng X.R., Yang G., Liu Z.Q., Li J., Liu Z.G., Li H.B., Yang P.C. (2016) Probiotics enhance the effect of allergy immunotherapy on regulating antigen specific B cell activity in asthma patients. Am. J. Transl. Res. 8: 5256-5270.

MacFaddin J. (2000) Biochemical Tests for Identification of Medical Bacteria. 3rd edition. Philadelphia, USA.

Mater D.D.G., Langella P., Corthier G., Flores M.J. (2008) A Probiotic Lactobacillus strain can acquire vancomycin resistance during digestive transit in mice. J. Mol. Microbiol. Biotechnol. 14: 123-127.

Mokoena M.P., Mutanda T., Olaniran A.O. (2016) Perspectives on the probiotic potential of lactic acid bacteria from African traditional fermented foods and beverages. Food Nutr. Res. 60: 29630.

Morrow L.E., Gogineni V., Malesker M.A. (2012) Probiotics in the intensive care unit. Nutrit. Clin. Pract. 27: 235-240.

Nahar A., Al-Amin M., Alam S.M.K., Wadud A., Islam M.N. (2007) A comparative study on the quality of dahi prepared from cow, goat and buffalo milk. Intern. J. Dairy Sci. 2: 260-267.

Najgebauer-Lejko D., Sady M. (2015) Estimation of the antioxidant activity of the commercially available fermented milks. Acta Sci. Pol. Technol. Aliment. 14: 387-396.

Pangallo D., Drahovska H., Harikova J., Ferianc P., Timko J. (2008) Assessment of environmental enterococci, bacterial antagonism, pathogenic capacity, and antibiotic resistance. Antonie Van Leeuwenhoek 94: 555-562.

Riberio A.C., Riberio A.C. (2010) Speciality products made from goat milk. Small Rumin Resist. 89: 225- 233.

Ruszczyński M., Horvath A., Dziechciarz P., Szajewska H. (2016) Cow's milk allergy guidelines: a quality appraisal with the AGREE II instrument. Clin. Exp. Allergy. 46(9): 1236-1241.

Schrezenmeir J., De Vrese M. (2001) Probiotics, prebiotics and synbiotics: approaching a definition. Amer. J. Clin. Nutr. 73: 361S-364S.

Sharma P., Tomar S.K., Goswami P., Sangwan S.R. (2014) Antibiotic resistance among commercially available probiotics. Food Res. Int. 57: 176-195.

Thoesen J.C. (1994) Suggested procedures for the detection and identification of certain finfish and shellfish pathogens. 4th edition. Version 1, fish Health Section, American Fisheries Society.

Zhang S., Zhang L., Han X. (2015) Lactic acid bacteria proteinase and quality of fermented dairy products - a review. Wei Sheng Wu Xue Bao. 55(12): 1530-1536. 